\title{
SIMULATION OF ULTRASONIC FIELDS PROPAGATING THROUGH NONPARALLEL BOUNDARIES
}

\author{
R.J. Kažys, L. Mažeika, and E. Jasiūnienė \\ Ultrasound Institute, Kaunas University of Technology, Studentu 50, LT-51368 Kaunas, Lithuania \\ E-mail: elena.jasiuniene@ktu.lt
}

Received 05 May 2004

Dedicated to the 100th anniversary of Professor K. Baršauskas

\begin{abstract}
The main objective of this paper is to present an efficient method suitable for simulation of ultrasonic fields radiated through the layers with nonparallel boundaries. The proposed method enables fast calculation of an ultrasonic disk-shaped transducer field transmitted through parallel and nonparallel boundaries between layers. The proposed simulation method is based on transformation of a multilayered medium into a virtual one without internal boundaries, equivalent to the actual medium from the point of view of the relative times of arrival of direct and edge waves. Such an approach enables one to exploit the modified axially symmetric model and to simplify the computations essentially. The example of simulated fields is presented for the case of plastic materials.
\end{abstract}

Keywords: ultrasonic fields, simulation, nonparallel boundaries

PACS: 43.20.-f, 43.20.+g, 43.38.+n

\section{Introduction}

In ultrasonic measurement and nondestructive testing instruments, ultrasonic waves are very often radiated by a piezoelectric transducer through a layer with nonparallel boundaries, or a prism. This layer is used for wave mode transformation or protection from the aggressive medium in which measurements are performed.

When an ultrasonic wave is radiated through the layer with nonparallel boundaries, the structure of the ultrasonic field becomes complicated, because the ultrasonic wave at the boundary is refracted in one plane and not refracted in the orthogonal plane. Due to this the ultrasonic field is not axially symmetric. In general, calculation of such fields requires application of three-dimensional models.

Objective of this work was to present a method suitable for simulation of ultrasonic fields radiated through the layers with nonparallel boundaries and to analyse the structure of the fields in a transient mode. For this purpose the known model for calculation of the field of a single circular transducer in homogeneous media was extended to the case of multilayered media with nonparallel boundaries. The proposed simulation method is based on transformation of a multilayered medium into a virtual medium without internal boundaries equivalent to the actual one from the point of a view of the relative times of flight of direct and edge waves.

\section{Generalized spatial pulse response function approach}

Experimental observations of the pulsed field of a circular ultrasonic transducer were compared with the results of an ideal circular piston radiator calculated using the well-known diffraction model [1]. The analysis of experimental results showed that field point waveforms and transmitter-receiver mode responses are in reasonable agreement with theoretical results calculated assuming ideal piston behaviour of the transducer $[1,2]$. These studies had also demonstrated the presence of the plane and edge waves in the radiated field [1-6]. The whole surface of a piston generates a direct plane wave, which propagates in a cylindrical region having the piston at its base. From the edge of the transducer diffracted edge waves are radiated, which propagate in all directions.

The pulsed field of the circular transducer in homogeneous media can be calculated using a mathematical 

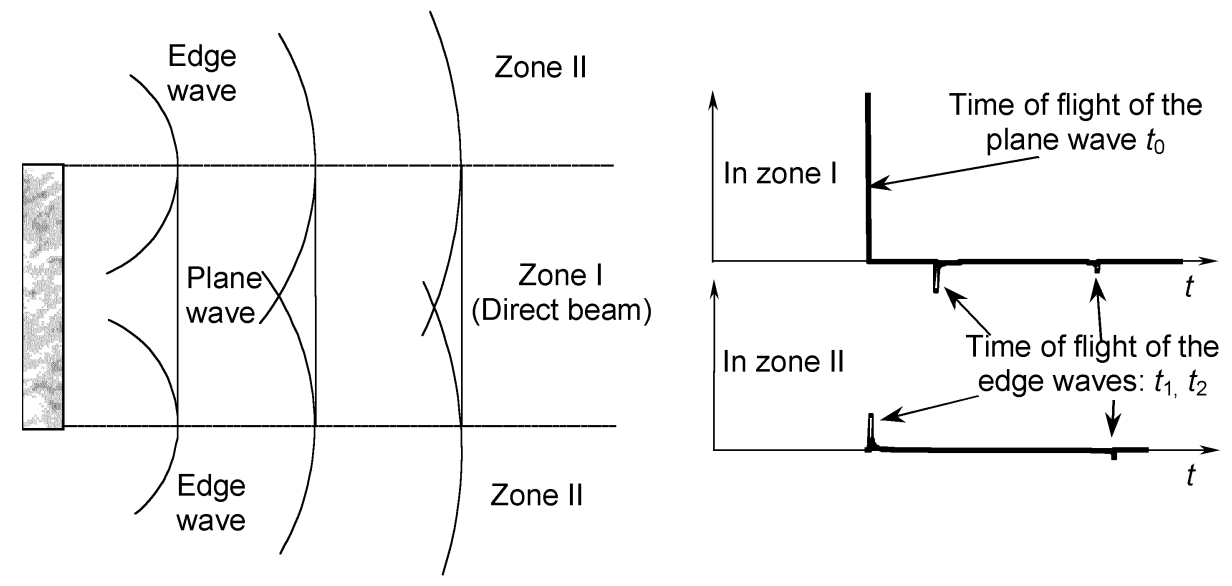

Fig. 1. Pulse response of the circular transducer in a homogeneous medium.

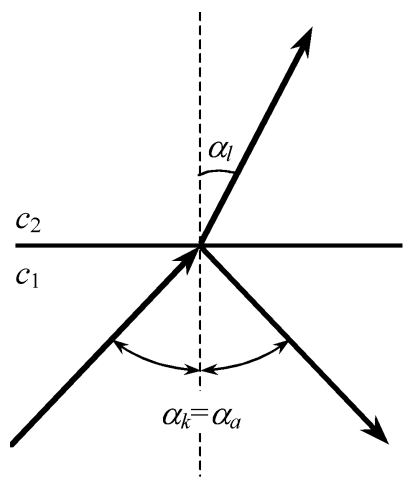

Fig. 2. Reflection and refraction of the plane wave on the boundary between two media.

model based on the spatial pulse response approach [7], that is, response of the transducer to excitation by a very short pulse. Typical waveforms of the spatial pulse response are given in Fig. 1. It can be seen that a big part of energy is concentrated in three pulses. The first pulse corresponds to the arrival time of a plane wave from the surface of a transducer. The second and the third pulses correspond to the arrival times of edge waves from the nearest and farthest edges of the diskshaped transducer.

The main assumption of the proposed method is the following: after refraction at the boundary between two media the ultrasonic field consists both of plane and edge waves. This means that even after passing the boundary, the shape of the spatial pulse response remains the same as in the case of a homogeneous medium, only the delay time of spikes in the spatial pulse response are different.

It is quite complicated to simulate the propagation of an ultrasonic wave through the boundary between two media, because at the boundary the refraction and transformation of waves takes place. When the ultra- sonic wave reaches the boundary, part of the wave is transmitted to the second medium and part of the wave is reflected. Which part of the energy is transmitted and which part is reflected, depends on the type of the transmitted wave, on the incidence angle, and on the acoustical properties of both media. The refraction angle of the wave is determined using Snell's law (Fig. 2):

$$
\frac{\sin \alpha_{k}}{\sin \alpha_{l}}=\frac{c_{1}}{c_{2}},
$$

where $\alpha_{k}$ is the incidence angle, $\alpha_{l}$ is the refraction angle, $c_{1}$ is the ultrasound velocity in the first medium, and $c_{2}$ is the ultrasound velocity in the second medium.

The angle of reflection $\alpha_{a}$ is equal to the angle of incidence $\alpha_{k}$ (Fig. 2). What types of waves will be generated (surface, leaky waves, etc.), when the wave passes the boundary, depends on the type of the incident wave, the incidence angle, and on the acoustical properties of both media. However, impact of the surface waves is not so big, and we are interested in ultrasonic field of the transducer in the far field zone, where the main influence is of longitudinal and share waves.

Calculating the path along which an acoustic ray propagates, it is assumed that each ray has to obey the Snell's and reflection laws. Usually these laws are applied to the plane waves, but after some assumptions it is possible to apply them also for other types of waves [8]. It has been assumed that the Snell's and reflection laws are valid for each ray, which is transmitted from any point of the transducer. If the trajectory of the ray from the point on the surface of the transducer to the point in the second medium has to be calculated, a point on the boundary between two media has to be found such that the angles of incidence, reflection, and refraction would satisfy the Snell's and reflection laws. 
Ultrasonic field of the circular transducer, when the wave passes the nonparallel boundary between two media, is calculated in the following way:

(1) the time of flight $t_{0}$ of the plane wave from the surface of the transducer to the given point is calculated;

(2) the times of flight $t_{1}$ and $t_{2}$ of the edge waves to the given point are calculated;

(3) an equivalent point in a virtual homogeneous medium, where the times of flight $t_{0}, t_{1}$, and $t_{2}$ are the same as in the medium with boundaries, is found;

(4) using the modified algorithm, the spatial pressure pulse response for the equivalent point in the virtual homogeneous medium is calculated;

(5) acoustic pressure at the given point is found by means of convolution of the spatial pulse response and the driving signal.

\section{Calculation of ultrasonic field}

\subsection{Calculation of the time of flight of the plane wave}

The time of flight of the plane wave $t_{0}$ from the surface of the circular transducer to the given point $P(x, z)$ is equal to the sum of the time of flight of the plane wave in the first medium $t_{01}$ and the time of flight of the plane wave in the second medium $t_{02}$ :

$$
t_{0}=t_{01}+t_{02}=\frac{r_{01}}{c_{1}}+\frac{r_{02}}{c_{2}},
$$

where $r_{01}$ is the distance that the ray propagates in the first medium, $r_{02}$ is the distance that the ray propagates in the second medium, $c_{1}$ is the ultrasound velocity in the first medium, and $c_{2}$ is the ultrasound velocity in the second medium.

In order to find the distances that a plane wave has to pass in the first and the second medium, a point on the boundary between two media has to be found such that the ray would obey the Snell's law at this point. For that, the time of flight of the plane wave from the centre of the transducer to the given $z$ coordinate $t_{0 c}$ has to be found (Fig. 3):

$$
t_{0 c}=\frac{r_{01 c}}{c_{1}}+\frac{r_{02 c}}{c_{2}},
$$

where $r_{01 c}$ is the propagation path of the ray in the first medium, $r_{02 c}$ is the propagation path of the ray in the second medium. Please note that in Fig. 3 geometry of the problem is presented in the plane $x 0 z$.

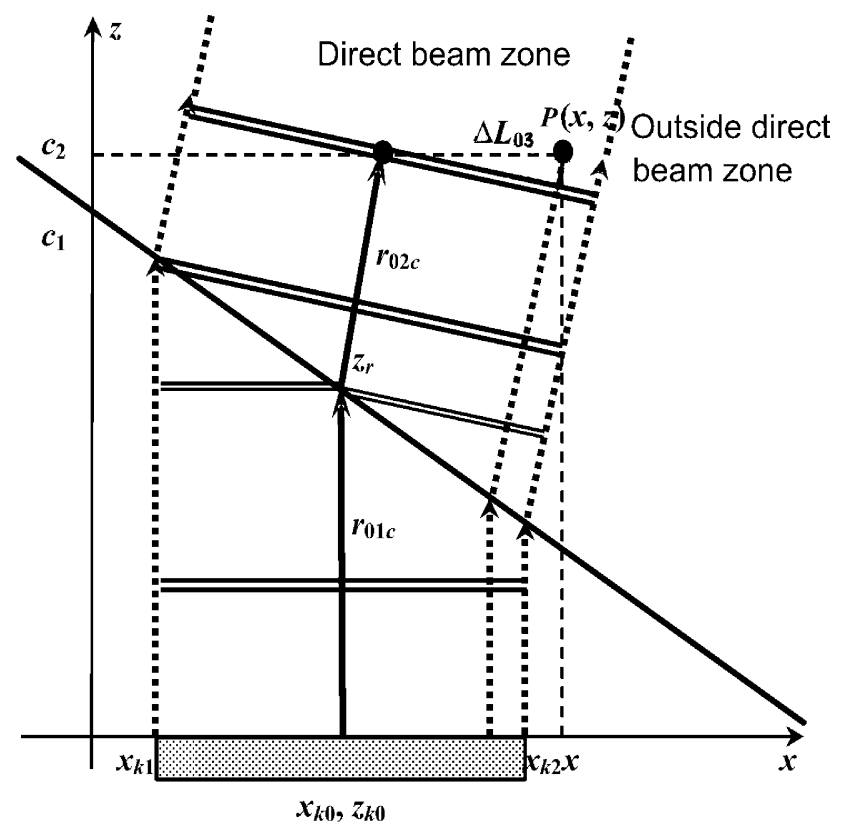

Fig. 3. Determination of the time of flight of the plane wave.

The delay of the wavefront $t_{0 v}$ to the point $P(x, z)$ with respect to the central ray is

$$
t_{0 v}=\frac{\Delta L_{03}}{c_{2}}
$$

where $\Delta L_{03}$ is the difference in distance that the ray has to propagate to the point $P(x, z)$ with respect to the central ray.

So, the time of flight of the plane wave to the given point $P(x, z)$ is

$$
t_{0}=t_{0 c}+t_{0 v}
$$

\subsection{Calculation of the times of flight of the edge waves $t_{1}, t_{2}$}

The times of flight of the edge waves $t_{1}$ and $t_{2}$ may be found in the following way (Fig. 4):

$$
\begin{aligned}
& t_{1}=\frac{r_{11}}{c_{1}}+\frac{r_{12}}{c_{2}}, \\
& t_{2}=\frac{r_{21}}{c_{1}}+\frac{r_{22}}{c_{2}},
\end{aligned}
$$

where $r_{11}, r_{21}$ are the distances that the edge wave propagates in the first medium, $r_{12}, r_{22}$ are the distances that the edge wave propagates in the second medium.

In order to find the distances that the edge waves have to propagate in the first and the second medium, points $P_{p 1}\left(x_{p 1}, z_{p 1}\right)$ and $P_{p 2}\left(x_{p 2}, z_{p 2}\right)$ on the boundary between the two media have to be found such that the 


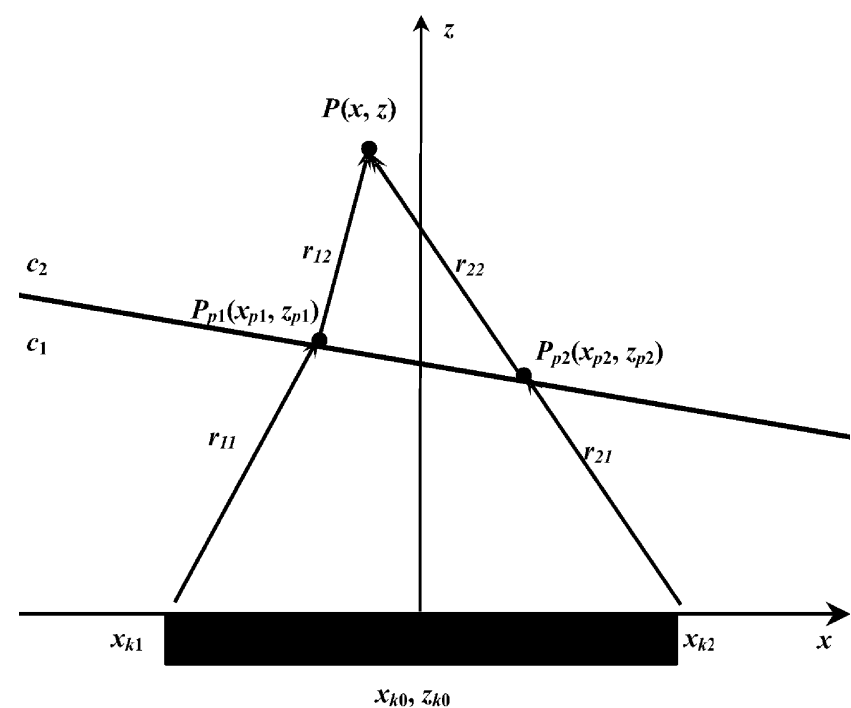

Fig. 4. Determination of the times of flight of the edge waves.

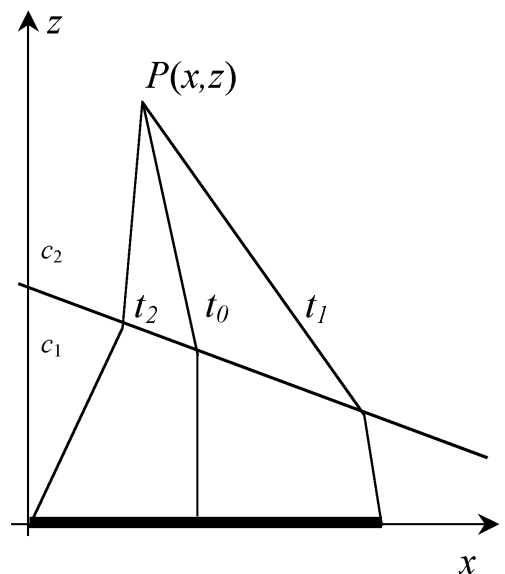

(a)

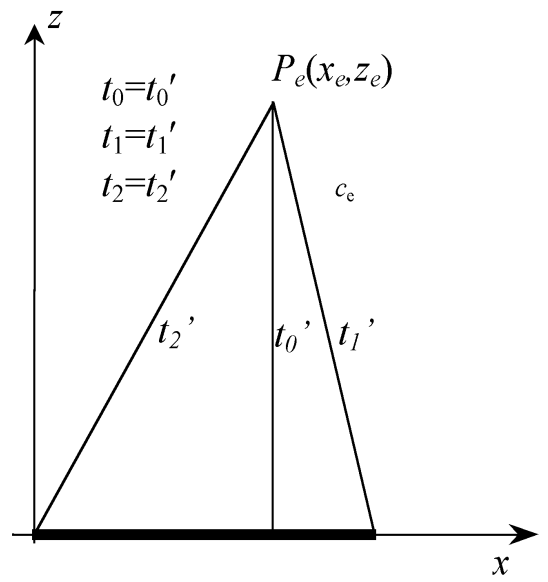

(b)

Fig. 5. Determination of the equivalent point in the virtual medium without boundaries: (a) medium with boundaries, (b) equivalent virtual medium without boundaries.

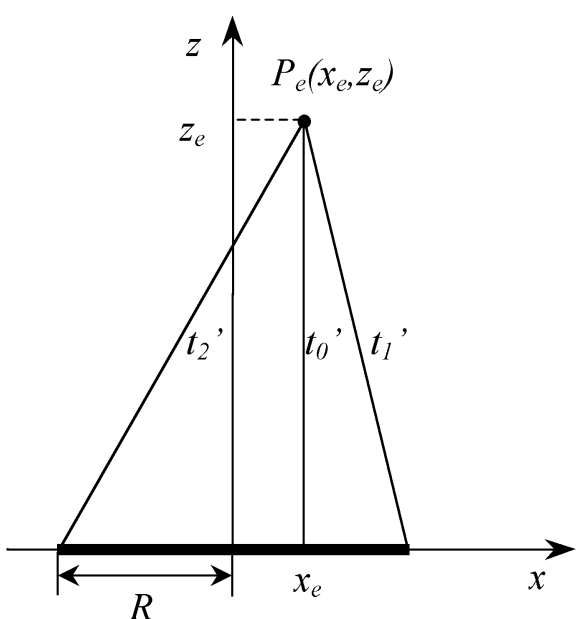

(a)

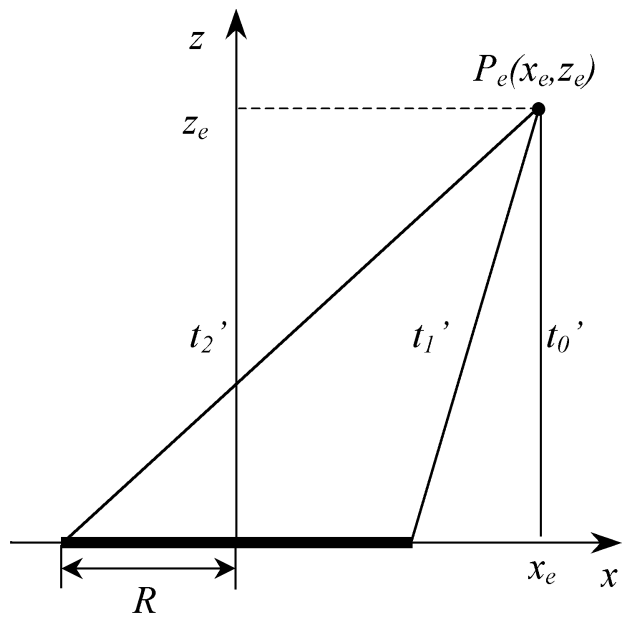

(b)

Fig. 6. Determination of the equivalent point in the virtual homogeneous medium: (a) $x_{e}<R$, (b) $x_{e}>R$.

rays corresponding to the edge waves would obey the Snell's law at these points (Fig. 4). The distances that the edge waves propagate in both media can be found using the following system of equations:

$$
\left\{\begin{array}{l}
c_{1} \cdot \sin \left(\alpha_{l 1}\right)=c_{2} \cdot \sin \left(\alpha_{k 1}\right), \\
c_{1} \cdot \sin \left(\alpha_{l 2}\right)=c_{2} \cdot \sin \left(\alpha_{k 2}\right),
\end{array}\right.
$$

where $\alpha_{k 1}, \alpha_{k 2}$ are the incidence angles of the edge wave to the second medium, $\alpha_{l 1}, \alpha_{l 2}$ are the refraction angles of the edge waves.

This system of equations has no analytical solution, therefore, the solution for parallel and nonparallel boundaries is found using numerical methods, shifting the points $P_{p 1}\left(x_{p 1}, z_{p 1}\right)$ and $P_{p 2}\left(x_{p 2}, z_{p 2}\right)$ on the boundary between two media until the given point obeys the Snell's law. 


\subsection{Determination of the equivalent point in a virtual homogeneous medium}

In Fig. 5(a) the real medium with boundaries is presented, where the times of flight are $t_{0}, t_{1}$, and $t_{2}$. The equivalent point $P_{e}\left(x_{e}, z_{e}\right)$ in the virtual homogeneous medium, where the times of flight $t_{0}^{\prime}, t_{1}^{\prime}$, and $t_{2}^{\prime}$ are the same as in the medium with boundaries, is presented in Fig. 5(b). Formulas for calculation of the ultrasound velocity in the virtual medium and for finding the equivalent point coordinates are derived using Fig. 6.

In the direct beam zone (Fig. 6(a)) the equivalent ultrasound velocity $c_{e}$ and the coordinates of the equivalent point $P_{e}\left(x_{e}, z_{e}\right)$ in the virtual homogeneous medium can be expressed as

$$
\begin{aligned}
& c_{e}=\frac{2 R}{\sqrt{t_{2}^{2}-t_{0}^{2}}+\sqrt{t_{1}^{2}-t_{0}^{2}}}, \\
& x_{e}=R-c_{e} \sqrt{t_{2}^{2}-t_{0}^{2}}, \\
& z_{e}=t_{0} c_{e} .
\end{aligned}
$$

Outside the direct beam zone (Fig. 6(b)) the equivalent ultrasound velocity $c_{e}$ and the coordinates of the equivalent point $P_{e}\left(x_{e}, z_{e}\right)$ in the virtual homogeneous medium can be expressed as

$$
\begin{aligned}
& c_{e}=\frac{2 R}{\sqrt{t_{2}^{2}-t_{0}^{2}}-\sqrt{t_{1}^{2}-t_{0}^{2}}}, \\
& x_{e}=R+c_{e} \sqrt{t_{2}^{2}-t_{0}^{2}}, \\
& z_{e}=t_{0} c_{e} .
\end{aligned}
$$

\subsection{Calculation of the spatial pulse response for an equivalent point in the virtual homogeneous medium}

The pulse response $h(t)$ for the equivalent point in the virtual homogeneous medium, when $x=x_{e}$, $z=z_{e}$, is found by means of the mixed analyticalnumerical procedure presented in [9]. This approach enables one to simulate an ultrasonic field in two media separated by an interface. The input parameters for this model are the transducer diameter, the ultrasound velocities $c_{1}, c_{2}$, and the densities $\rho_{1}, \rho_{2}$ corresponding to the first and the second medium.

The pulsed field of the transducer can be calculated using the mathematical model based on the spatial pulse response approach [7]. The spatial pressure pulse response of the disk transducer with radius $R$ is given by the following expressions:

$$
h_{t}(x, z, t)=\left\{\begin{array}{lc}
-\rho_{0} c \delta\left(t-t_{0}\right), & x<R, t_{0} \leq t<t_{1}, \\
-\frac{\rho_{0} c}{\pi} \frac{\mathrm{d} \theta}{\mathrm{d} t}, & x<R, t_{1} \leq t \leq t_{2}, \\
-\rho_{0} c\left[\delta\left(t-t_{0}\right)+\frac{1}{\pi} \frac{\mathrm{d} \theta_{1}}{\mathrm{~d} t}\right], & x=R, t_{0} \leq t \leq t_{2}, \\
-\frac{\rho_{0} c}{\pi} \frac{\mathrm{d} \theta}{\mathrm{d} t}, & x>R, t_{1} \leq t \leq t_{2},
\end{array}\right.
$$$$
\frac{\mathrm{d} \theta}{\mathrm{d} t}=\frac{1}{c^{2} t^{2}-z^{2}}
$$

$$
\times \frac{-c^{2} t\left(c^{2} t^{2}-z^{2}-x^{2}+R^{2}\right)}{\sqrt{4\left(c^{2} t^{2}-z^{2}\right) R^{2}-\left(c^{2} t^{2}-z^{2}-x^{2}+R^{2}\right)^{2}}},
$$

$\frac{\mathrm{d} \theta_{1}}{\mathrm{~d} t}=-\frac{c^{2} t}{\sqrt{\left(c^{2} t^{2}-z^{2}\right)\left[4 R^{2}-\left(c^{2} t^{2}-z^{2}\right)\right.}}$,

$$
t_{0}=\frac{z}{c},
$$

$$
\begin{aligned}
& t_{1}=\frac{\sqrt{(R-x)^{2}+z^{2}}}{c}, \\
& t_{2}=\frac{\sqrt{(R+x)^{2}+z^{2}}}{c},
\end{aligned}
$$

where $\rho_{0}$ is the density of the medium, $c$ is the ultrasound velocity, $t_{0}$ is the delay time of the plane wave from the transducer surface to the point with coordinates $(x, z), t_{1}$ is the delay time of the edge wave from the nearest transducer edge to the point with coordinates $(x, z), t_{2}$ is the delay time of the edge wave from the farthest transducer edge to the point with coordinates $(x, z)$.

\subsection{Convolution of the spatial pulse response and the driving signal}

The acoustic pressure at an arbitrary point $(x, y)$ is found as convolution of the driving pulse $u(t)$ and the spatial pulse response $h(x, z, t)$ :

$$
p_{a}(x, z, t)=k_{c} \int_{0}^{\infty} u(\tau) h(x, z, t-\tau) \mathrm{d} \tau,
$$




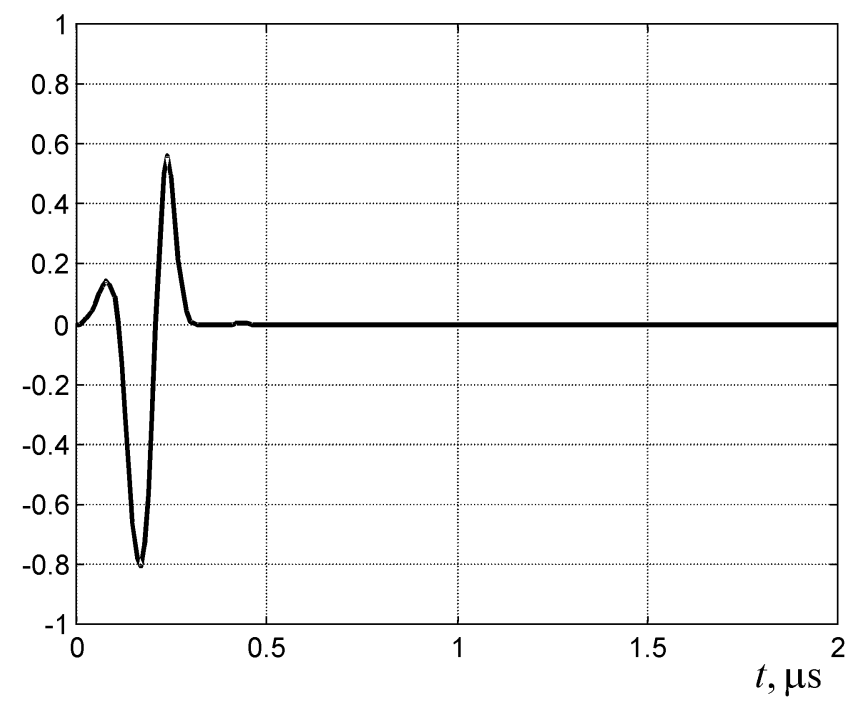

Fig. 7. Waveform of the driving ultrasonic pulse.

where $k_{c}$ is a constant factor and $h(t)$ is the pulse response of a circular transducer, radiating through layers with nonparallel boundaries.

The driving signal was approximated by

$$
u(t)=\exp \left\{a(t-b)^{2}\right\} \sin (2 \pi f t),
$$

where $a=k_{a} f \sqrt{-2 \ln 0.1 / p_{s}}, b=2 p_{s} /(3 f), p_{s}$ is the number of periods, $k_{a}$ is the asymmetry factor, $f$ is the frequency. Such a signal has a shape of a highfrequency ( $f=5 \mathrm{MHz}$ ) pulse with the Gaussian envelope (Fig. 7). Steepness of the front and back slopes of the pulse can be set separately selecting the corresponding value of $k_{a}$. Simulation was carried out for a short pulse $\left(p_{s}=1.5\right)$.

\section{Simulation results}

Calculations of the transient ultrasonic fields and waveforms in the time domain were performed for the plastic material-water structure with parallel and nonparallel boundaries between these two media (Fig. 8). The thickness of the first layer (plastic material) at the central axis was assumed to be $10 \mathrm{~mm}$. Calculations were performed for the two cases: when the boundary between the two media was parallel (Fig. 8(a)) and when the boundary had an inclination angle of $5^{\circ}$ (Fig. 8(b)). The calculations were performed for the circular transducer of the radius $R=6 \mathrm{~mm}$ and with the frequency $f=2 \mathrm{MHz}$. The ultrasound velocity in the first layer (plastic material) was assumed to be $c_{b}=2500 \mathrm{~m} / \mathrm{s}$, in the second layer (water) $c=1480 \mathrm{~m} / \mathrm{s}$. The calculated pressure field is presented in Fig. 9 as a spatial distribution of peak val-

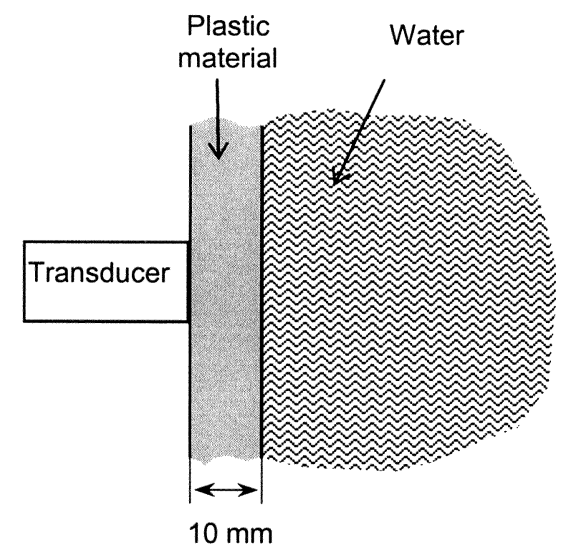

(a)

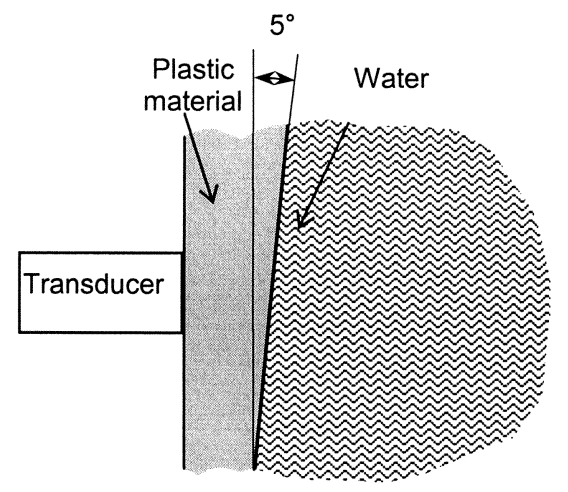

(b)

Fig. 8. The plastic material-water structure with parallel and nonparallel boundaries used for simulation of ultrasonic fields.

ues of the pressure $p_{c s}(x, z)=\max _{t}|p(x, z, t)|$. For better understanding the presented field is normalized with respect to the maximum value of the pressure in the second medium.

The simulated ultrasonic field of the transducer in the first medium (plastic material) and the second medium (water) in the case of parallel boundaries between the two media is presented in Fig. 9(a). The circular ultrasonic transducer is located at $z=0$, $x= \pm 6 \mathrm{~mm}$. The simulated ultrasonic field in the case of nonparallel boundaries between the two media is presented in Fig. 9(b).

In the case of parallel boundaries the field possesses axial symmetry, therefore, the presented spatial field structure is the same in any plane passing through the axis of the transducer orthogonal to the surface of the transducer. In the case of nonparallel boundaries the ultrasonic field is shown in the plane passing through the axis of the transducer, and in which the inclination of the boundary is the largest. In this plane the largest refraction of the ultrasonic beam takes place (Fig. 9(b)). 


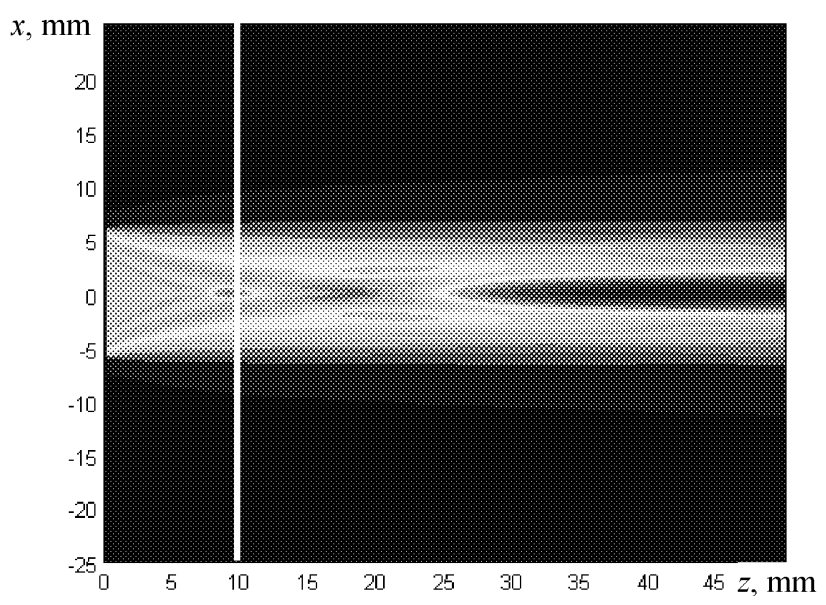

(a)

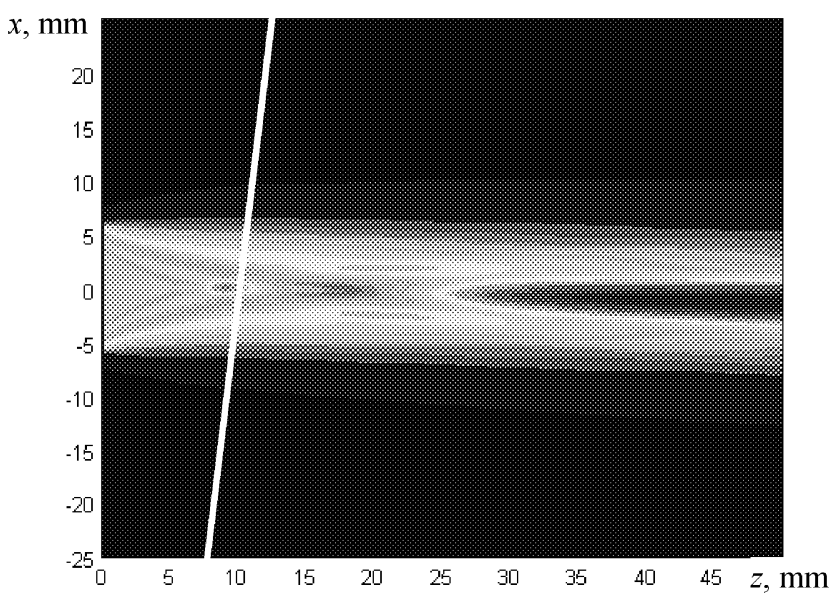

(b)

Fig. 9. The simulated ultrasonic field after passing the nonparallel boundary between two media: (a) the layer with parallel boundaries, (b) the layer with nonparallel boundaries. The white line indicates the position of the boundary plastic material-water.

\section{Conclusions}

In this paper the method for simulation of ultrasonic fields excited by circular transducers in media with nonparallel boundaries is presented. The proposed method enables fast calculation of an ultrasonic disktype transducer field transmitted through parallel and nonparallel boundaries between layers. The presented examples of the simulated fields illustrate influence of the nonparallel boundaries on the spatial structure of ultrasonic fields transmitted through such boundaries.

\section{References}

[1] J.P. Weight and A.J. Hayman, Observations of the propagation of very short ultrasonic pulses and their reflection by small targets, J. Acoust. Soc. Am. 63(2), 396404 (1978).

[2] A.J. Hayman and J.P. Weight, Transmission and reception of short ultrasonic pulses by circular and square transducers, J. Acoust. Soc. Am. 66(4), 945-951 (1979).

[3] J.N. Tjotta and S. Tjotta, Near field and far-field of pulsed acoustic radiators, J. Acoust. Soc. Am. 71(4), 824-834 (1982).

[4] G.R. Harris, Transient field of a baffled planar piston having an arbitrary vibration amplitude distribution, J. Acoust. Soc. Am. 70(1), 186-204 (1981).

[5] A. Weins, Radiation field calculations of pulsed ultrasonic transducers, Part 1: Planar circular, square and annular transducers, Ultrasonics 7, 183-188 (1980).

[6] A. Lhemery, Impulse response method to predict echo responses from targets of complex geometry, Part I: Theory, J. Acoust. Soc. Am. 90(5), 2799-2807 (1991).

[7] D.E. Robinson, S. Lees, and L. Bess, Near field transient radiation patterns for circular pistons, IEEE Trans. Acoust. Speech Sign. Proc. ASSP-22, 395-405 (1974).

[8] M. El Amrani, P. Calmon, O. Roy, D. Royer, and O. Casula, The ultrasonic field of focused transducers through a liquid-solid interface, in: Review of Progress in Quantitative Nondestructive Evaluation, Vol. 14 (1995) pp. 1075-1082.

[9] E. Jasiūnienė and L. Mažeika, The modified method for simulation of ultrasonic fields of disk shape transducer, Ultragarsas (Ultrasound) 3(33), 33-37 (Technologija, Kaunas, 1999). 


\title{
ULTRAGARSINIŲ LAUKŲ, SKLINDANČIŲ PER NELYGIAGREČIAS RIBAS, MODELIAVIMAS
}

\author{
R.J. Kažys, L. Mažeika, E. Jasiūnienè
}

Ultragarso mokslo institutas, Kauno technologijos universitetas, Kaunas, Lietuva

\begin{abstract}
Santrauka
Terpèse su nelygiagrečiomis ribomis ultragarsinio lauko sandara tampa sudètinga, nes ultragarsinè banga lūžta vienoje plokštumoje ir nelūžta kitoje. Dẻl to ultragarsinis laukas nèra simetriškas ašies atžvilgiu. Bendru atveju tokius laukus modeliuoti reikia taikant 3D modelius. Pagrindinis šio darbo tikslas buvo pateikti veiksmingą metodą, tinkamą modeliuoti ultragarsiniams laukams, sklindantiems per sluoksnius su nelygiagrečiomis ribomis. Pasiūlytas modeliavimo metodas remiasi daugiasluoksnès terpès pakeitimu tariama vienalyte terpe, îvertinant santykines plokščios bangos ir krašto bangu sklidimo trukmes. Tai leidžia naudoti pakeistą simetrišką ašies atžvilgiu modelį ir supaprastinti skaičiavimus. Naudoto metodo pagrindinè prielaida yra ta, kad, bangai perejus dviejų ter-
\end{abstract}

pių ribą, ultragarsinis laukas taip pat susideda iš plokščiųu ir krašto bangu, t. y. po perèjimo per ribą impulsinès charakteristikos forma yra tokia pati, kaip ir vienalytès medžiagos atveju, tik skiriasi laikiniai parametrai. Apskaičiuodami kiekvieno spindulio nuo keitiklio nueitą kelią priimam, kad Snelijaus dèsnis galioja ir plokščioms, ir krašto bangoms, t. y. jis galioja kiekvienam bet kurio keitiklio taško išspinduliuotam spinduliui. Norint apskaičiuoti spindulio kelią nuo taško keitiklio paviršiuje iki taško antroje terpejje, būtina rasti toki spindulio kritimo tašką dviejų medžiagu riboje, kad krintančio ir praejjusio spindulio kampai tenkintų Snelijaus dèsni. Pateikti ultragarsinių laukų sklidimo per lygiagrečią ir nelygiagrečią ribą tarp dviejų medžiagu modeliavimo rezultatai parodo ribų įtaką ultragarsinio lauko sandarai. 